Postprint of C.R. Borra, Y. Pontikes, K. Binnemans, T. Van Gerven (2015). Leaching of rare earths from bauxite residue (red mud). Accepted for publication in Minerals Engineering.

\title{
Leaching of rare earths from bauxite residue (red mud)
}

\author{
Chenna Rao Borra ${ }^{a}$, Yiannis Pontikes ${ }^{b}$, Koen Binnemans ${ }^{c}$ and Tom Van Gerven ${ }^{a^{*}}$ \\ ${ }^{a}$ Department of Chemical Engineering, KU Leuven, 3001 Leuven, Belgium \\ ${ }^{\mathrm{b}}$ Department of Materials Engineering, KU Leuven, 3001 Leuven, Belgium \\ ${ }^{c}$ Department of Chemistry, KU Leuven, 3001 Leuven, Belgium
}

*Corresponding author. E-mail address: tom.vangerven@ cit.kuleuven.be

\begin{abstract}
Bauxite residue (or red mud) is a waste generated during the Bayer process of alumina production. Its storage is a spatial and environmental concern. Currently, there are no bulk applications of bauxite residue except for minor use in cements and ceramics. Nonetheless, some types of bauxite residues are rich in rare-earth elements (REEs), and the extraction of scandium in particular is of special interest. Leaching experiments on Greek bauxite residue were performed with different acids at different concentrations, liquid-to-solid ratios, leaching times and temperatures. Extraction of the REEs was high for leaching in $\mathrm{HCl}$ solutions compared to other acids, but the dissolution of iron was high as well ( $60 \%)$. The maximum extraction of the REEs was around $80 \%$. Sodium and calcium were completely dissolved during leaching. Dissolution of aluminium, silicon and titanium was between 30 and 50\%. The leaching data show a very close association of scandium with the iron oxide phases.
\end{abstract}

Key words: Bauxite Residue; Lanthanides; Leaching; Rare earths; Red mud; Waste processing 
Postprint of C.R. Borra, Y. Pontikes, K. Binnemans, T. Van Gerven (2015). Leaching of rare earths from bauxite residue (red mud). Accepted for publication in Minerals Engineering.

\section{INTRODUCTION}

Bauxite is the major ore for aluminium production. Alumina is extracted from bauxite by the Bayer process. The waste slurry generated in this process is called red mud and its solid fraction is called bauxite residue. About 1-2 metric tonnes of bauxite residue is generated for each tonne of alumina produced (Kumar et al., 2006). The global annual generation of bauxite residue is around 120 million tonnes and 2.7 billion tonnes of this material has already been stockpiled (Klauber et al., 2011). The pH of the wet red mud slurry is about 12. It is stored in huge tailing ponds and this poses a significant problem, since it not only occupies vast land areas, but it can also lead to environmental pollution (Power et al., 2011). Hence, there is a need for better management strategies (preferably utilization) of the bauxite residue. However, currently there are not many large-volume applications of bauxite residue besides minor use in cement and ceramic production (Binnemans et al., 2013; Klauber et al., 2011; Kumar et al., 2006; Pontikes and Angelopoulos, 2013). Nonetheless, bauxite residue contains several interesting minor or trace elements, among which the rare-earth elements (REEs). More than $90 \%$ of the trace metal value in bauxite residue can be attributed to the presence of one of these REEs, namely scandium (Binnemans et al., 2013). Considering the revived interest on REEs due to supply concerns, novel research in the area is likely to take place.

Bauxite ores are classified in three different ways based on: (1) genetic principles: (1a) bauxites on igneous and metamorphic rocks; (1b) bauxites on sediments: carbonate rocks and clastic strata; (2) geological age: (2a) Palaezoic; (2b) Mesozoic; (2c) Cenozoic; and (3) mineralogical composition: (3a) gibbsite bauxites; (3b) boehmite bauxites; (3c) diasporic bauxites (Valeton, 1972). The bauxites on carbonate rocks (karst) have higher REE concentrations compared to other bauxites (Mordberg, 1993). Karst bauxites are mainly located in Europe, Jamaica, Russia and China. These bauxites account for 14\% of total bauxite reserves 
Postprint of C.R. Borra, Y. Pontikes, K. Binnemans, T. Van Gerven (2015). Leaching of rare earths from bauxite residue (red mud). Accepted for publication in Minerals Engineering.

(Bárdossy, 1982). The REEs report in the Bayer process to bauxite residue. The enrichment factor of the REEs in bauxite residue compared to bauxite is about two (Ochsenkühn-Petropulu et al., 1994). REEs are present in bauxite as mineral phases or as ions that are either absorbed on the surface of minerals or replacing similar ions in the lattice of some matrix minerals (Li et al., 2013).

Some literature data on the leaching of REEs from bauxite residue are available (Fulford et al., 1991; Ochsenkühn-Petropulu et al., 1996; Ochsenkühn-Petropulu et al. 2002; Qu and Lian, 2013; Smirnov and Molchanova, 1997; Wang et al., 2011; Wang et al., 2013; Xue et al., 2010; Yatsenko and Pyagai, 2010; Zhang et al., 2005). Fulford et al. (1991) developed a process for the extraction of REEs from Jamaican bauxite residue using sulfur dioxide, whereby REEs are selectively dissolved while leaving iron and titanium substantially undissolved in the bauxite residue. Ochsenkühn-Petropulu et al. (1996) compared metal leaching extraction with different acids, different acid concentrations and different leaching conditions. Their results showed that $0.5 \mathrm{~N} \mathrm{HNO}_{3}$ leaching at $25^{\circ} \mathrm{C}$ for $24 \mathrm{~h}$ with a liquid-to-solid (L/S) ratio of $50: 1$ recovered $80 \%$ of scandium, $90 \%$ of yttrium, $70 \%$ of the heavy lanthanides (Dy, Er, $\mathrm{Yb}$ ), $50 \%$ of the middle ones (Nd, Sm, Eu, Gd) and 30\% of the light lanthanides ( $\mathrm{La}, \mathrm{Ce}, \mathrm{Pr}$ ). The leaching process with dilute $\mathrm{HNO}_{3}$ was performed at pilot scale and optimized for the extraction of scandium from bauxite residue (Ochsenkühn-Petropulu et al., 2002). Xue et al. (2010) found that at a reaction temperature of $90{ }^{\circ} \mathrm{C}$ and an L/S ratio of 3:1, over $80 \%$ of the scandium in bauxite residue could be leached by $\mathrm{H}_{2} \mathrm{SO}_{4}$. Zhang et al. (2005) recovered $80 \%$ of scandium by $\mathrm{HCl}$ leaching at acid concentration of $6 \mathrm{~mol} / \mathrm{L} \mathrm{HCl}, \mathrm{L} / \mathrm{S}$ ratio of $4: 1$, temperature of $50{ }^{\circ} \mathrm{C}$ and a reaction time of $1 \mathrm{~h}$. Wang et al. (2010) studied the extraction of scandium from bauxite residue by using $\mathrm{HCl}$ as leaching agent, with an $\mathrm{L} / \mathrm{S}$ ratio of 5:1, an acid concentration of $6 \mathrm{~mol} / \mathrm{L}$, a reaction temperature 
Postprint of C.R. Borra, Y. Pontikes, K. Binnemans, T. Van Gerven (2015). Leaching of rare earths from bauxite residue (red mud). Accepted for publication in Minerals Engineering.

of $50{ }^{\circ} \mathrm{C}$ and a reaction time of $1 \mathrm{~h}$. Qu et al. (2013) leached REEs and radioactive elements from bauxite residue by bioleaching.

The majority of the literature studies focus upon scandium and very little on other REEs. Neither has much work been done on leaching of major elements from bauxite residue nor leaching of REEs by organic acids. Study on the leaching of major elements is, however, useful for the development of the further purification process. Therefore, in this study we systematically investigated the extraction of REEs as well as other major elements in organic and mineral acids ( $\mathrm{HCl}, \mathrm{HNO}_{3}, \mathrm{H}_{2} \mathrm{SO}_{4}, \mathrm{CH}_{3} \mathrm{COOH}, \mathrm{CH}_{3} \mathrm{SO}_{3} \mathrm{H}$ and citric acid). The effect of different parameters such as acid type and concentration, leaching time, liquid-to-solid ratio and temperature were investigated.

\section{EXPERIMENTAL}

The bauxite residue studied in this work was provided by the Aluminum of Greece Company, which is located at Agios Nikolaos, Greece. It is originated from a mixture of karst and lateritic bauxites and is similar to the bauxite residue examined by Ochsenkühn-Petropulu et al. (1994). It was received from the alumina refinery after dewatering by filter presses and room temperature drying. The sample was further dried at $105{ }^{\circ} \mathrm{C}$ for $12 \mathrm{~h}$. Next, the material was passed through a $500 \mu \mathrm{m}$ size mesh before it was used in leaching studies. Analytical reagent grade nitric acid (65\%) (Chem-lab), sulfuric acid (95-97\%) (Sigma-Aldrich), hydrochloric acid (37\%) (Fisher Scientific), acetic acid (100\%) (VWR International), citric acid (99.6\%) (Acros Organics) and methanesulfonic acid (98\%) (Acros Organics) were used in the present study. Chemical analysis of major elements in bauxite residue was performed using wavelength dispersive X-ray fluorescence spectroscopy (WDXRF, Panalytical PW2400). Chemical analysis of minor elements was performed after complete dissolution of bauxite residue by alkali fusion 
Postprint of C.R. Borra, Y. Pontikes, K. Binnemans, T. Van Gerven (2015). Leaching of rare earths from bauxite residue (red mud). Accepted for publication in Minerals Engineering.

and acid digestion in a 1:1 (v/v) $\mathrm{HCl}$ solution, followed by Inductively Coupled Plasma Mass

Spectrometry (ICP-MS, Thermo Electron X Series) analysis. The alkali fusion was carried out by mixing $0.5 \mathrm{~g}$ of bauxite residue with $1.5 \mathrm{~g}$ of sodium carbonate and $1.5 \mathrm{~g}$ of sodium tetraborate decahydrate, followed by heating the mixture in a platinum crucible at $1100{ }^{\circ} \mathrm{C}$ for $30 \mathrm{~min}$. The mineralogy of the samples was studied by X-ray diffraction technique (XRD, Philips PW1830). The powder morphology was investigated by scanning electron microscopy (SEM, Philips XL30). The particle size of the samples was measured by laser particle size analysis (Malvern Mastersizer 3000). Thermo-gravimetric analysis (TGA, Netzsch STA 409) experiments were carried out in nitrogen atmosphere from room temperature to $1000{ }^{\circ} \mathrm{C}$ at a heating rate of 10 ${ }^{\circ} \mathrm{C} / \mathrm{min}$.

The leaching of the bauxite residue was carried out in sealed polyethylene bottles by constant agitation using a laboratory shaker (Gerhardt Laboshake) at $160 \mathrm{rpm}$ and $25^{\circ} \mathrm{C}$. Hightemperature leaching experiments were carried out in a $500 \mathrm{~mL}$ glass reactor fitted with a reflux condenser and placed on a temperature-controlled ceramic hot plate with a magnetic stirring system. The leach solution sample was filtered using a syringe filter (pore size of $0.45 \mu \mathrm{m}$ ) and diluted with distilled water for ICP-MS analysis. Leaching experiments were repeated twice to assess the reproducibility and the error found was within the $10 \%$ range.

\section{RESULTS AND DISCUSSION}

\subsection{Characterisation of the bauxite residue}

The concentrations of the major elements in the form of oxides in Greek bauxite residue is given in Table 1. Iron oxide is the major oxide in the bauxite residue followed by alumina, silica, calcium oxide, titanium oxide and sodium oxide. The concentrations of the REEs is given in Table 2. The relative standard deviation was less than $20 \%$. From the table, it is evident that the 
Postprint of C.R. Borra, Y. Pontikes, K. Binnemans, T. Van Gerven (2015). Leaching of rare earths from bauxite residue (red mud). Accepted for publication in Minerals Engineering.

bauxite residue sample is richer in light REEs than in heavy REEs. It is also rich in scandium

(121 g/tonne). The total REE concentration is around $0.1 \mathrm{wt} . \%$.

Table 1. Major chemical components in the bauxite residue sample.

\begin{tabular}{|l|l|}
\hline Compound & wt. \% \\
\hline $\mathrm{Fe}_{2} \mathrm{O}_{3}$ & 44.6 \\
\hline $\mathrm{Al}_{2} \mathrm{O}_{3}$ & 23.6 \\
\hline $\mathrm{CaO}$ & 11.2 \\
\hline $\mathrm{SiO}_{2}$ & 10.2 \\
\hline $\mathrm{TiO}_{2}$ & 5.7 \\
\hline $\mathrm{Na}_{2} \mathrm{O}$ & 2.5 \\
\hline
\end{tabular}

Table 2. Rare-earth elements composition of the bauxite residue sample. Standard deviations are based on triplicate measurements. The detection limit of a REE is $1 \mathrm{~g} /$ tonne.

\begin{tabular}{|l|l|}
\hline Element & $\begin{array}{l}\text { Concentration } \\
\text { (g/tonne) }\end{array}$ \\
\hline $\mathrm{Sc}$ & $121 \pm 10$ \\
\hline $\mathrm{Y}$ & $75.7 \pm 9.6$ \\
\hline $\mathrm{La}$ & $114 \pm 15$ \\
\hline $\mathrm{Ce}$ & $368+68$ \\
\hline $\mathrm{Pr}$ & $28.0 \pm 3.9$ \\
\hline $\mathrm{Nd}$ & $98.6 \pm 7.0$ \\
\hline $\mathrm{Sm}$ & $21.3 \pm 2.3$ \\
\hline $\mathrm{Eu}$ & $5.0 \pm 0.9$ \\
\hline $\mathrm{Gd}$ & $22.0 \pm 1.9$ \\
\hline $\mathrm{Tb}$ & $3.5 \pm 0.6$ \\
\hline $\mathrm{Dy}$ & $16.7 \pm 0.7$ \\
\hline $\mathrm{Ho}$ & $3.9 \pm 0.6$ \\
\hline $\mathrm{Er}$ & $13.5 \pm 1.8$ \\
\hline $\mathrm{Tm}$ & $1.9 \pm 0.3$ \\
\hline $\mathrm{Yb}$ & $14.0 \pm 1.9$ \\
\hline $\mathrm{Lu}$ & $2.4 \pm 0.3$ \\
\hline
\end{tabular}

The following major minerals and compounds were identified by X-ray powder diffraction (XRD): the iron minerals hematite and goethite; the aluminum minerals gibbsite and diaspore; the calcium mineral calcite and the sodium compound cancrinite (Figure 1). TGA-DSC curves of the bauxite residue show three slopes (TGA) and three peaks (DSC) (Figure 2). The 
Postprint of C.R. Borra, Y. Pontikes, K. Binnemans, T. Van Gerven (2015). Leaching of rare earths from bauxite residue (red mud). Accepted for publication in Minerals Engineering.

weight loss between 300 and $600{ }^{\circ} \mathrm{C}$ is due to decomposition of hydroxides in different stages

(due to decomposition of gibbsite and goethite between 300 and $400{ }^{\circ} \mathrm{C}$ and of diaspore between 400 and $600{ }^{\circ} \mathrm{C}$ ) (Agatzini-Leonardou et al., 2008). The weight loss between 600 and $800{ }^{\circ} \mathrm{C}$ is due to the decomposition of calcium carbonate present in the sample.

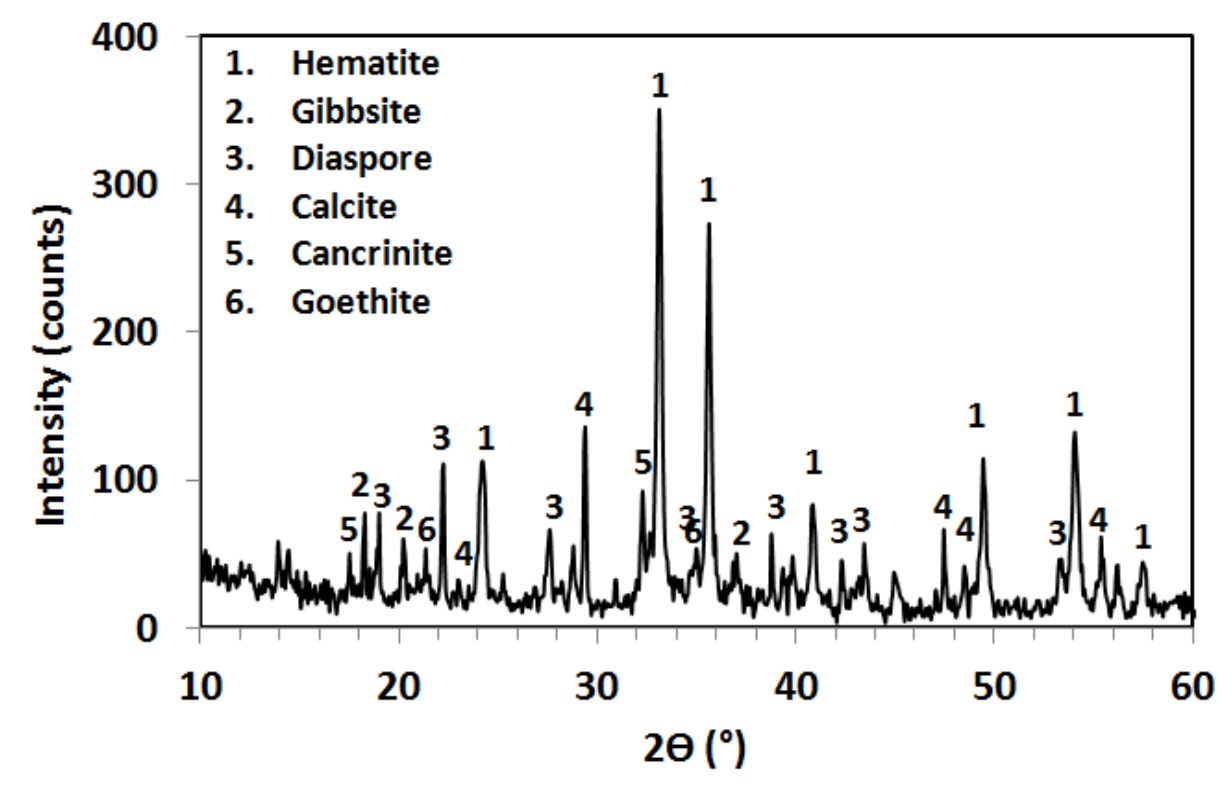

Figure 1. XRD pattern of the bauxite residue sample. 


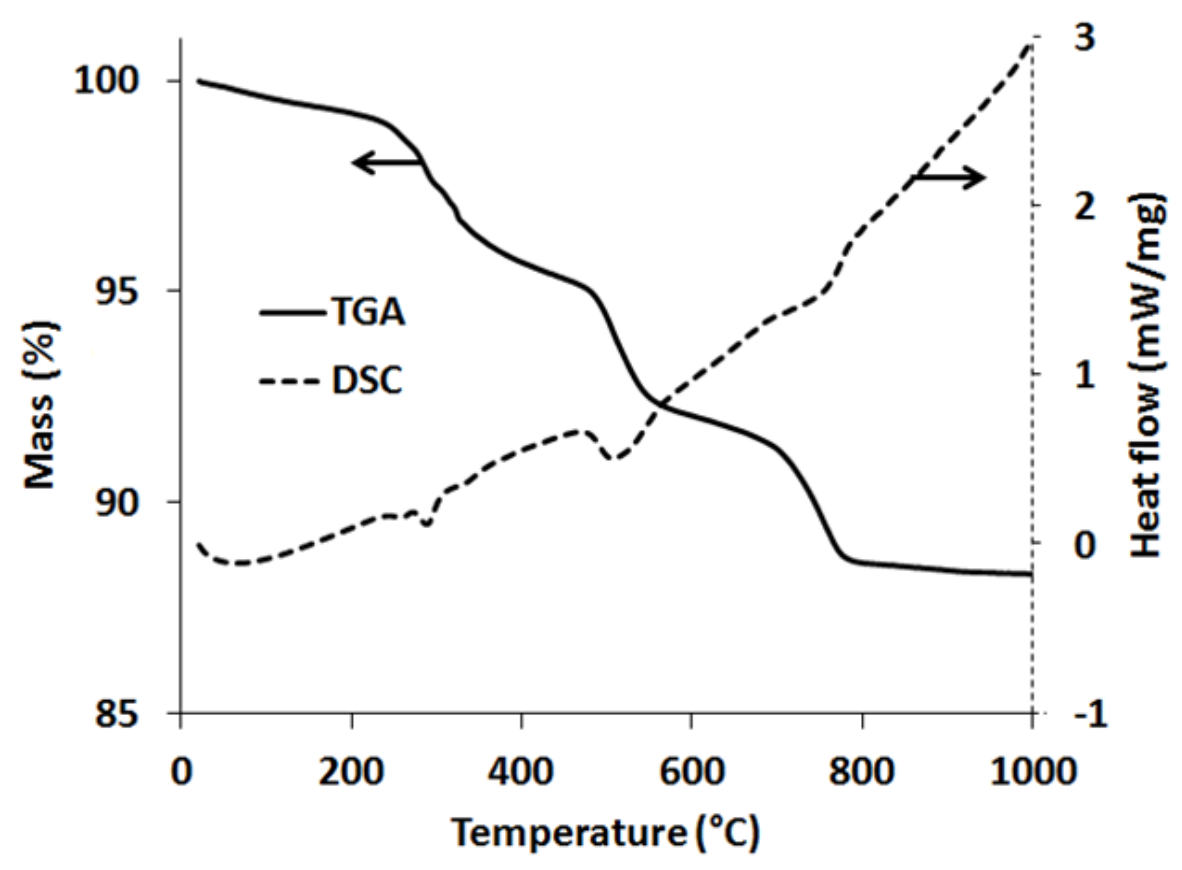

Figure 2. TGA and DSC curves of the bauxite residue sample.

The cumulative particle size distribution of the bauxite residue sample is shown in Figure 3. In the bauxite residue, $90 \%$ of the particles are smaller than $10 \mu \mathrm{m}$ and $50 \%$ of the particles are smaller than $0.06 \mu \mathrm{m}$. Scanning electron microscopy (SEM) was used to study the morphology of the sample. The SEM pictures show that the bauxite residue is a very fine material and that aggregates are formed (Figure 4). These results are in line with the particle size analysis. Particles larger than $10 \mu \mathrm{m}$ were also observed in the cross section of the sample. It was difficult to perform EDX analysis on the individual particles due to the interference by neighboring particles. However, some phases were identified by EDX analysis, such as aluminium hydroxide (gibbsite or diaspore), hematite, rutile, calcium carbonate, calcium titanate, sodium aluminosilicates. This confirms the results of XRD. It was impossible to identify the rare-earth mineral phases in the bauxite residue due to their low concentrations. Other authors experienced similar difficulties (e.g. Ochsenkühn-Petropulu et al., 1996). 


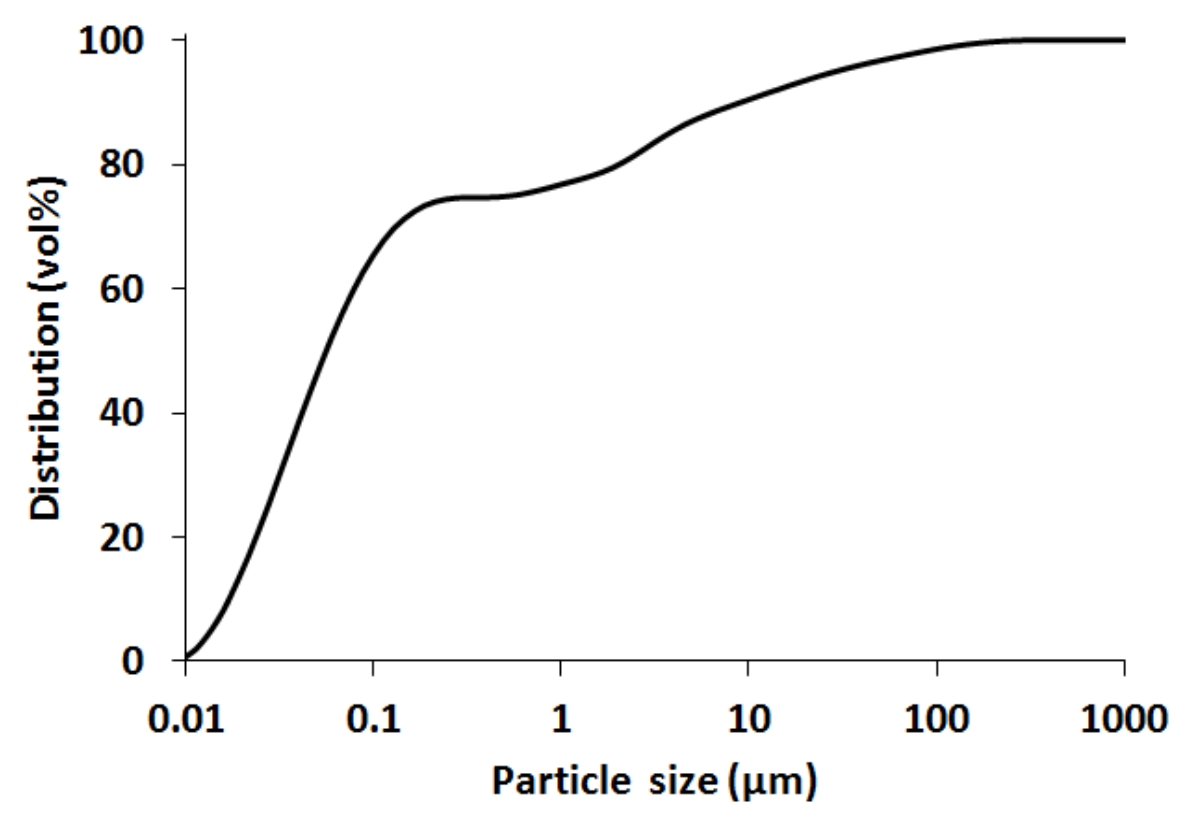

Figure 3. Cumulative particle size distribution of the bauxite residue sample.

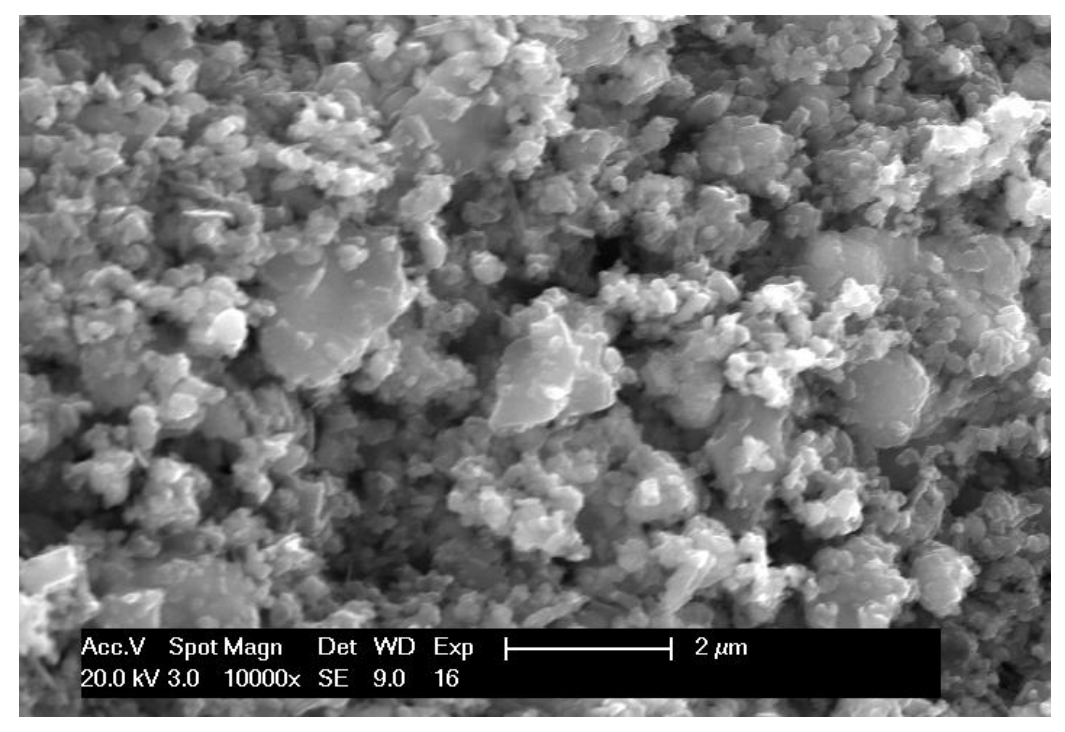

Figure 4. SEM image of the bauxite residue sample.

\subsection{Leaching with water}

Leaching studies with water were carried out to study the change in $\mathrm{pH}$ of bauxite residue and the possibility of sodium hydroxide removal prior to acid leaching. Prior removal by water 
Postprint of C.R. Borra, Y. Pontikes, K. Binnemans, T. Van Gerven (2015). Leaching of rare earths from bauxite residue (red mud). Accepted for publication in Minerals Engineering.

would be beneficial as this would reduce the amount of acid needed to merely neutralize the high $\mathrm{pH}$. The experiments were conducted at two L/S ratios: 5:1 and 50:1. Even after four washing steps, the $\mathrm{pH}$ of the solution did not decrease, i.e. the $\mathrm{pH}$ remained stable at around 10 . This is due to the buffering activity of alkaline solids that are present in the sample (Thornber and Binet, 1999). Figure 5 shows the sodium removal from the bauxite residue by water washing at different $\mathrm{L} / \mathrm{S}$ ratios. Around 10 to $15 \mathrm{wt} . \%$ of the total sodium content was removed from the solution after four washing steps. This is also due to the fact that most of the sodium in the bauxite residue is in the form of insoluble aluminosilicates. It can be concluded that water washing is not very efficient in neutralizing the $\mathrm{pH}$ prior to acid leaching. Therefore, the leaching study was performed using the bauxite residue without washing.

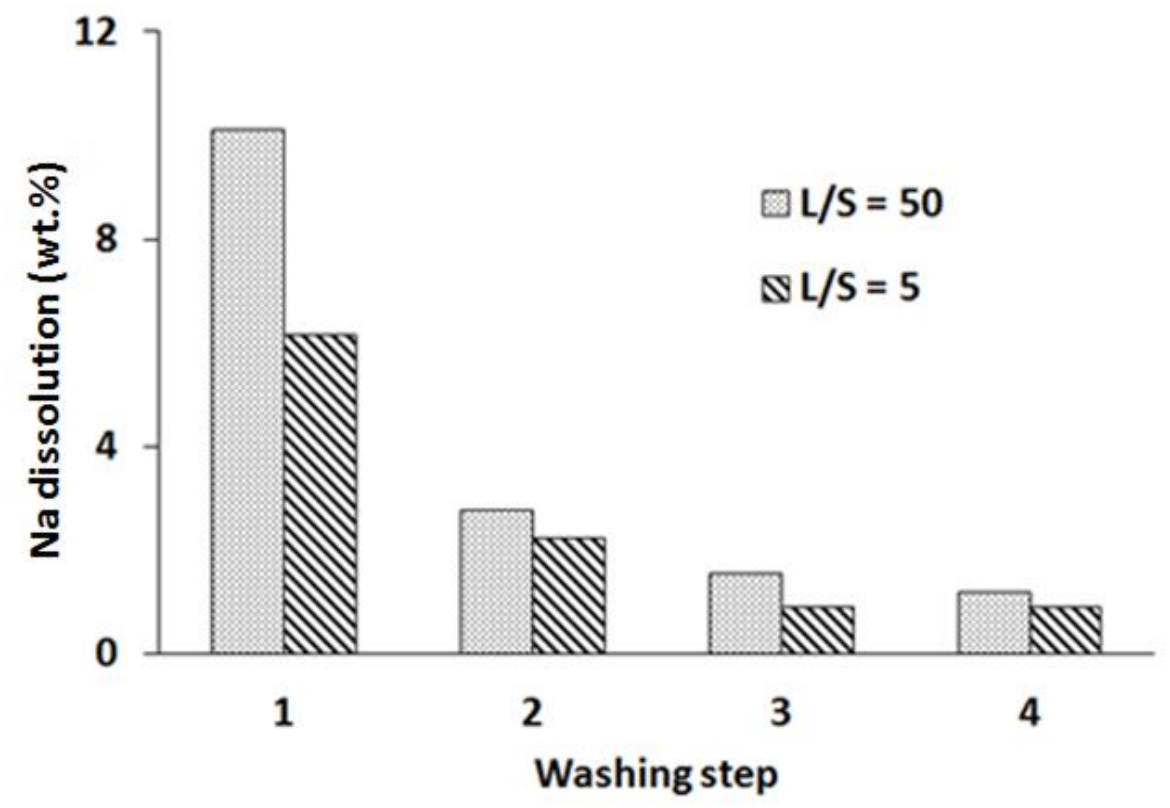

Figure 5. Sodium removal from the bauxite residue by washing with water.

\subsection{Leaching with acids}

\subsubsection{Acids of low concentration}


Postprint of C.R. Borra, Y. Pontikes, K. Binnemans, T. Van Gerven (2015). Leaching of rare earths from bauxite residue (red mud). Accepted for publication in Minerals Engineering.

Experiments were conducted at low acid concentrations $(<1 \mathrm{~N})$ of different mineral and organic acids to study the effect on $\mathrm{pH}$ and on leaching of different elements. Figure 6 shows the effect of acid concentration on the $\mathrm{pH}$ of the solution. From this figure, it is evident that with increase in the acid concentration, the $\mathrm{pH}$ is decreasing. The studied organic acids except methanesulfonic acid $\left(\mathrm{CH}_{3} \mathrm{SO}_{3} \mathrm{H}\right)$ are weak acids. Acetic acid $\left(\mathrm{CH}_{3} \mathrm{COOH}\right)$ is weaker than citric acid.

The effect of nitric acid concentration on the leaching of major elements is shown in Figure 7. Dissolution of $\mathrm{Ca}$ and $\mathrm{Na}$ is high even at $\mathrm{pH}$ values above 5. The dissolution of aluminium, silicon, titanium and iron is also increased with a decrease in $\mathrm{pH}$ and it reached a maximum when $\mathrm{pH}$ value is around 1 . The dissolution of aluminium and silicon increased simultaneously. This is due to dissolution of alumunium and silicon from the sodium aluminosilicates.

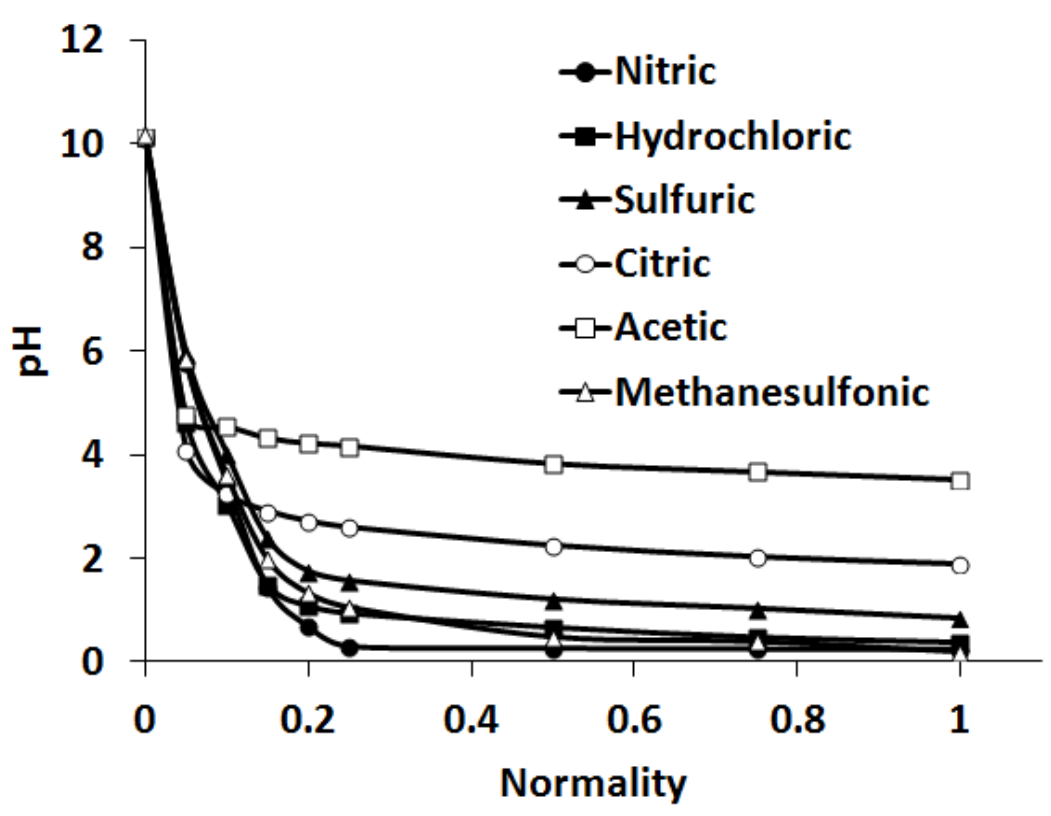

Figure 6. Effect of acid concentration on the $\mathrm{pH}$ of the bauxite residue sample $\left(\mathrm{T}: 25^{\circ} \mathrm{C}, \mathrm{L} / \mathrm{S}: 50\right.$, $\mathrm{t}: 24 \mathrm{~h})$. 


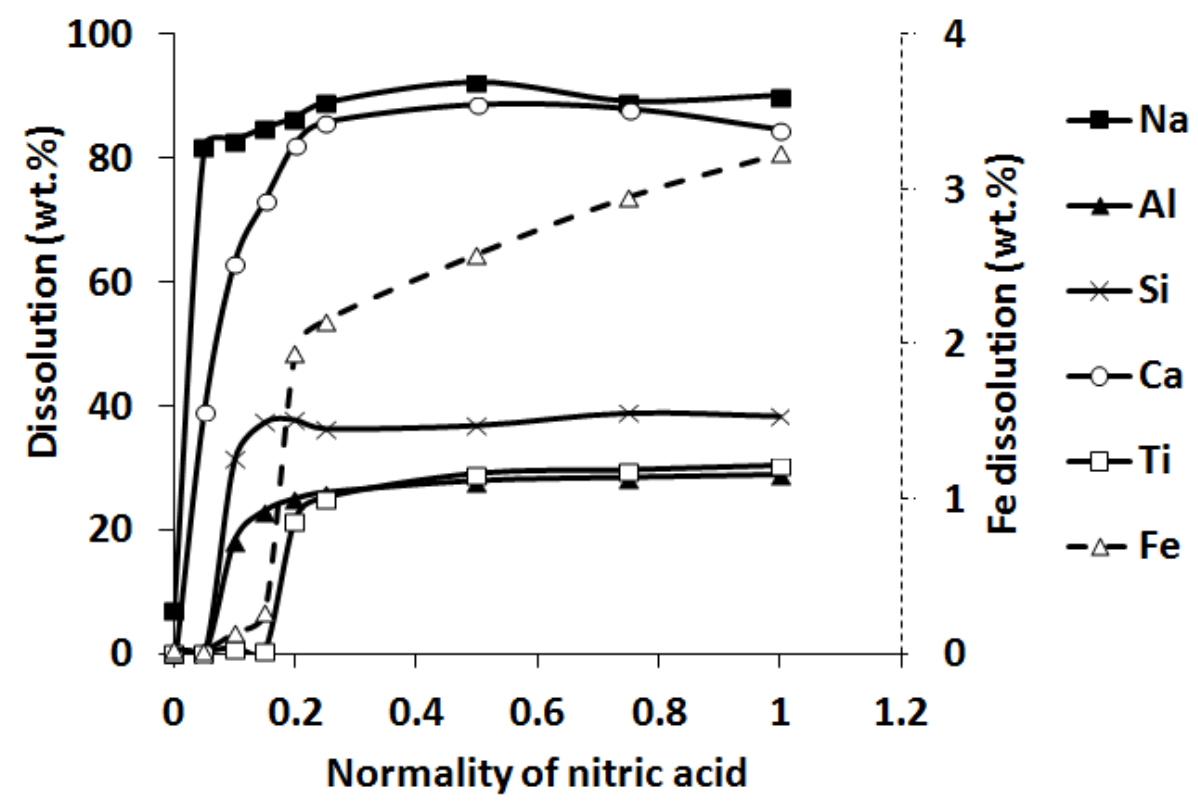

Figure 7. Effect of nitric acid concentration on dissolution of major elements in the bauxite residue sample (T: $\left.25^{\circ} \mathrm{C}, \mathrm{L} / \mathrm{S}: 50, \mathrm{t}: 24 \mathrm{~h}\right)$.

Figure 8 shows the effect of different acids and their concentrations on the leaching of REEs. Not all the REEs are shown in the figure for the sake of readability. Extraction of Sc, Y, $\mathrm{La}, \mathrm{Ce}, \mathrm{Nd}$ are shown as their concentrations are relatively high in bauxite residue. Dy is also shown because its concentration is the highest among the heavy REEs. Iron is indicated in the graph to illustrate the selectivity of leaching. Figure 8 shows that the leaching of REEs is increasing with increasing acid concentration up to $0.25 \mathrm{~N}$ acid concentration. Initially, acid is consumed for neutralization and dissolution of aluminosilicates. Leaching of REEs and major elements is almost similar for all mineral acids and methanesulfonic acid. The degree of dissolution of REEs, iron and titanium is lower in citric acid and is the lowest in acetic acid. This is attributed to the higher $\mathrm{pH}$ of the citric acid and acetic acid solutions, compared to the $\mathrm{pH}$ obtained with mineral acid leaching. Dissolution of iron may be low $(<5 \%)$ in the solution, but 
Postprint of C.R. Borra, Y. Pontikes, K. Binnemans, T. Van Gerven (2015). Leaching of rare earths from bauxite residue (red mud). Accepted for publication in Minerals Engineering.

the iron concentration is very high ( $300 \mathrm{ppm})$ compared to REEs ( $\sim 9 \mathrm{ppm})$ due to its high concentration in the sample.

The percentage extraction is different for different REEs. This is due to the association of REEs with different minerals and their ionic radii (Ochsenkühn-Petropulu et al., 1996; Qu and Lian, 2013). For example, some of the cerium in the bauxite residue is present in the form of $\mathrm{CeO}_{2}$ or bastnaesite $\left((\mathrm{Ce}, \mathrm{La}) \mathrm{CO}_{3} \mathrm{~F}\right)(\mathrm{Li}$ et al., 2013) and is difficult to leach. Scandium is present in the iron (III) oxide lattice (Brookins, 1988). Therefore, it is not completely soluble in the acid solutions unless iron is completely dissolved. The extraction is high for Y, followed by Dy, Nd, Sc, La and Ce. This order is slightly changed depending on the type and concentration of the applied acid. The leaching order is matching with the results given in the literature (OchsenkühnPetropulu et al., 1994) for the similar material. However, the extraction is lower in the present study, especially for Sc and Y. The difference is as high as $20 \%$. This may be due to a change in raw materials or process parameters that were used 20 years ago compared with the current conditions in the Bayer process. 
Postprint of C.R. Borra, Y. Pontikes, K. Binnemans, T. Van Gerven (2015). Leaching of rare earths from bauxite residue (red mud). Accepted for publication in Minerals Engineering.
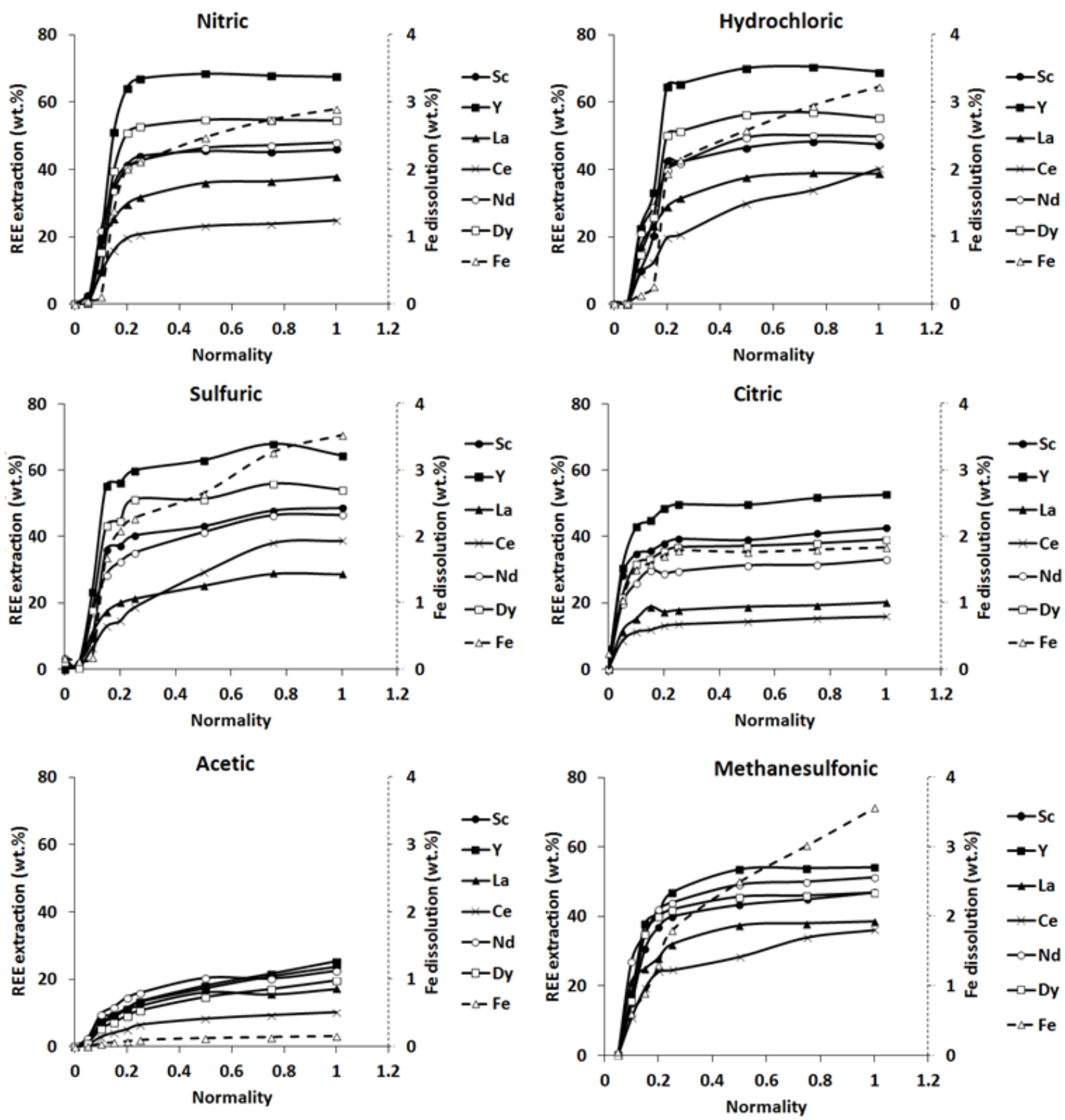

Figure 8. Effect of acid concentration on leaching of REEs from bauxite residue (T: $25{ }^{\circ} \mathrm{C}, \mathrm{L} / \mathrm{S}$ :

$50, \mathrm{t}: 24 \mathrm{~h})$.

\subsubsection{Acids of high concentration}


Postprint of C.R. Borra, Y. Pontikes, K. Binnemans, T. Van Gerven (2015). Leaching of rare earths from bauxite residue (red mud). Accepted for publication in Minerals Engineering.

Experiments were conducted at high concentrations $(>1 \mathrm{~N})$ of acids for $24 \mathrm{~h}$ with varying L/S ratio. The results for hydrochloric acid leaching are shown in Figure 9. It can be seen that an increase in the L/S ratio increases the extraction of elements from the bauxite residue. Extraction of the rare earths also increases with increasing acid concentration, as was already noted at acid concentrations $<1 \mathrm{~N}$. Extraction of $\mathrm{Y}, \mathrm{Nd}$ and Dy is higher than $80 \%$, while that of Sc, La and Ce is around $70-80 \%$ at acid concentration of $6 \mathrm{~N}$. Iron dissolution is increased with increasing acid concentration from less than $5 \%$ at $0.5 \mathrm{~N}$ acid concentration to around $60 \%$ at $6 \mathrm{~N}$ acid concentration. Titanium dissolution increased to around $60 \%$ at $6 \mathrm{~N}$ acid concentration and L/S ratio of 50:1. The recoveries were higher for $\mathrm{HCl}$ leaching compared to $\mathrm{HNO}_{3}$ and $\mathrm{H}_{2} \mathrm{SO}_{4}$, which may be due to the higher dissolution of iron.
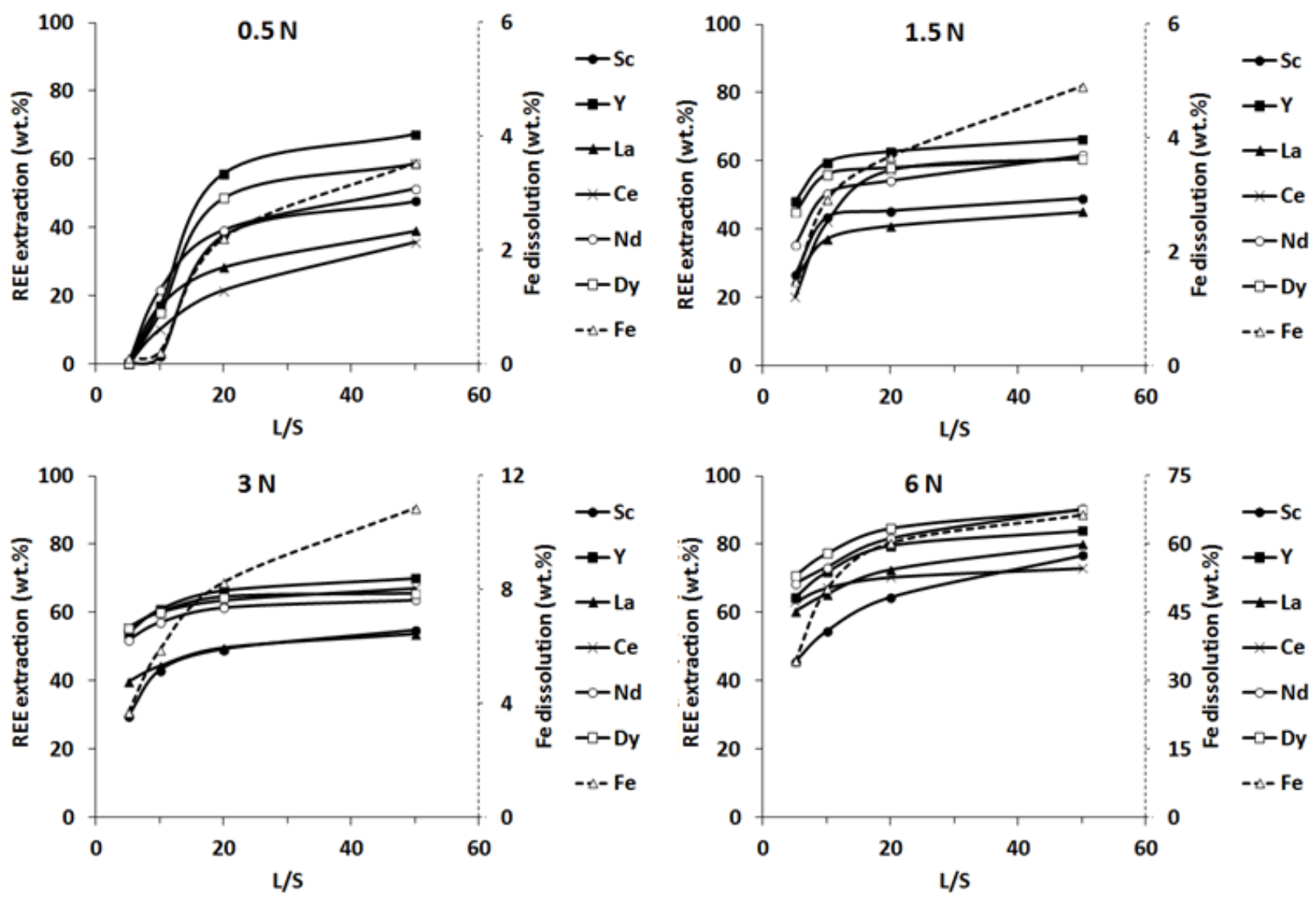

Figure 9. Effect of acid concentration and L/S ratio on extraction of REEs in bauxite residue ( $\left.\mathrm{HCl}, \mathrm{T}: 25^{\circ} \mathrm{C}, \mathrm{t}: 24 \mathrm{~h}\right)$. 
Postprint of C.R. Borra, Y. Pontikes, K. Binnemans, T. Van Gerven (2015). Leaching of rare earths from bauxite residue (red mud). Accepted for publication in Minerals Engineering.

\subsubsection{Correlation between leaching of REE and major elements}

Leaching results of REE's were plotted against major elements at a given L/S ratio (50) to evaluate their association with different oxides. The best correlation was found between iron and scandium for all the acids used in the study (Figure 10). This figure shows that about $50 \%$ of the scandium in the bauxite residue samples can be recovered without bringing too much iron into solution. However, trying to recover more than $50 \%$ of the scandium will inevitably result in dissolution of a major part of the iron. It will not be possible to recover $100 \%$ of the scandium present in the bauxite residue without dissolving all of the iron. This shows that at least part of the scandium is closely associated with the iron oxide phases. This is a nice illustration of the chemical similarity between scandium and iron, an observation that was first made by Urbain and Sarkar (1927). On the other hand, the curve in Figure 10 also shows that the scandium is not homogeneously distributed throughout the iron oxide phases. Either the scandium is present in different minerals or it is enriched in the outer layer of the iron oxide particles or adsorbed on the surface of the particles. The two most abundant iron minerals are goethite and hematite, which exhibit similar dissolution behavior in acid conditions (Roach, 1970). Therefore, it is more likely that the scandium leaching is controlled by diffusion from the outer layer and/or desorption from the surface. This explains why about $50 \%$ of the scandium can be recovered with limited dissolution of iron, whereas for a small increase in scandium extraction beyond the $50 \%$ requires dissolution of a much larger part of the iron. No good correlation was observed between the dissolution of iron and yttrium, the lanthanides and the major elements. A linear relationship $\left(\mathrm{R}^{2}\right.$ $>0.99$ ) was observed for the extraction of different adjacent REE's, with the exception of the scandium and cerium (Figure 11). This is due to the difference in the association of scandium and chemical behavior of tetravalent cerium compared to other rare earths. 
Postprint of C.R. Borra, Y. Pontikes, K. Binnemans, T. Van Gerven (2015). Leaching of rare earths from bauxite residue (red mud). Accepted for publication in Minerals Engineering.

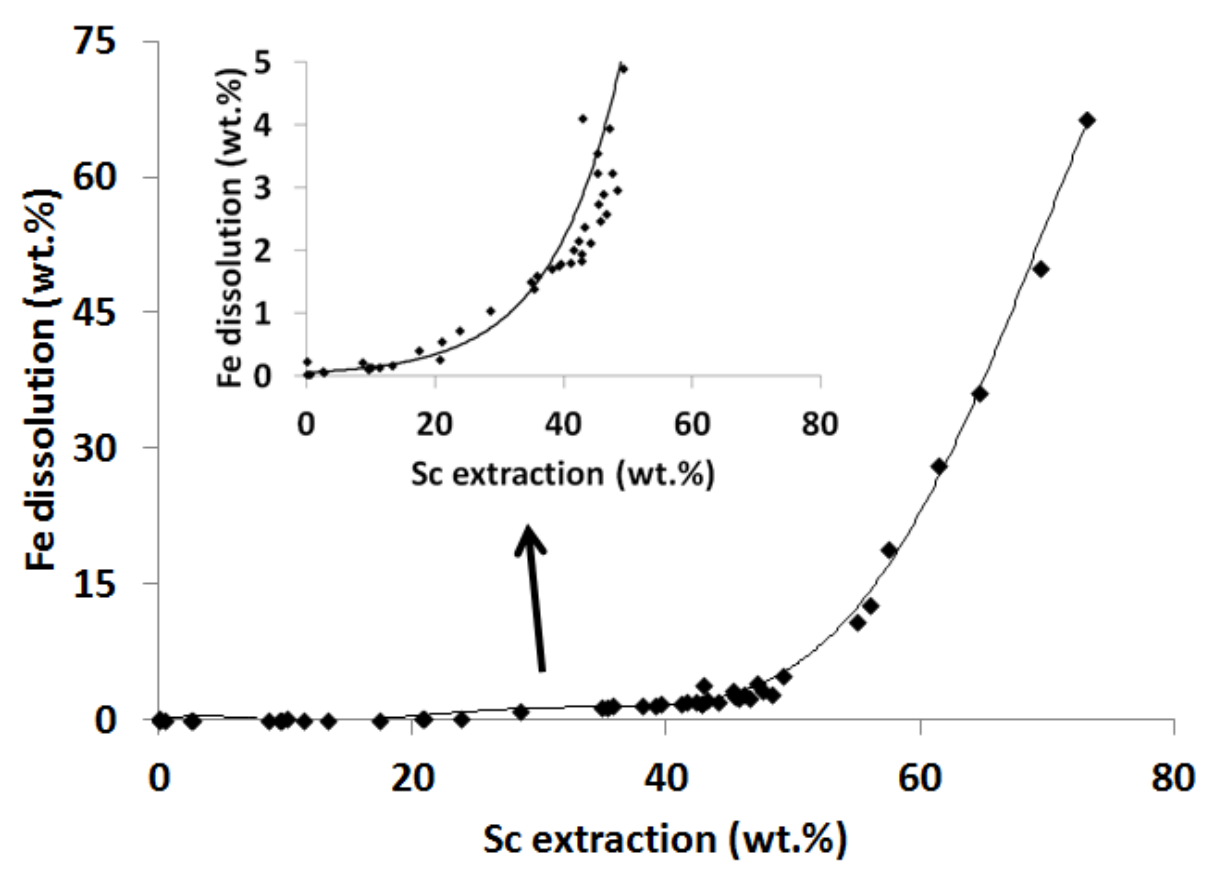

Figure 10. Correlation between dissolution of iron and scandium for leaching experiments with different types and concentrations of acids (T: $\left.25^{\circ} \mathrm{C}, \mathrm{L} / \mathrm{S}: 50, \mathrm{t}: 24 \mathrm{~h}\right)$. 



Figure 11. Correlation between dissolution of different rare earths for leaching experiments with different types and concentrations of acids (T: $\left.25^{\circ} \mathrm{C}, \mathrm{L} / \mathrm{S}: 50, \mathrm{t}: 24 \mathrm{~h}\right)$.

Figure 12 shows the effect of acid concentration on selective leaching of scandium in $\mathrm{HCl}$. The figure shows that both iron and scandium extraction increases with increase acid concentration at a specific L/S ratio. At a given acid concentration iron and scandium leaching concentrations are increasing with increase in L/S ratio. An acid concentration lower than $3 \mathrm{~N}$ is beneficial to leach maximum scandium and keeping less amount of iron in the solution. 


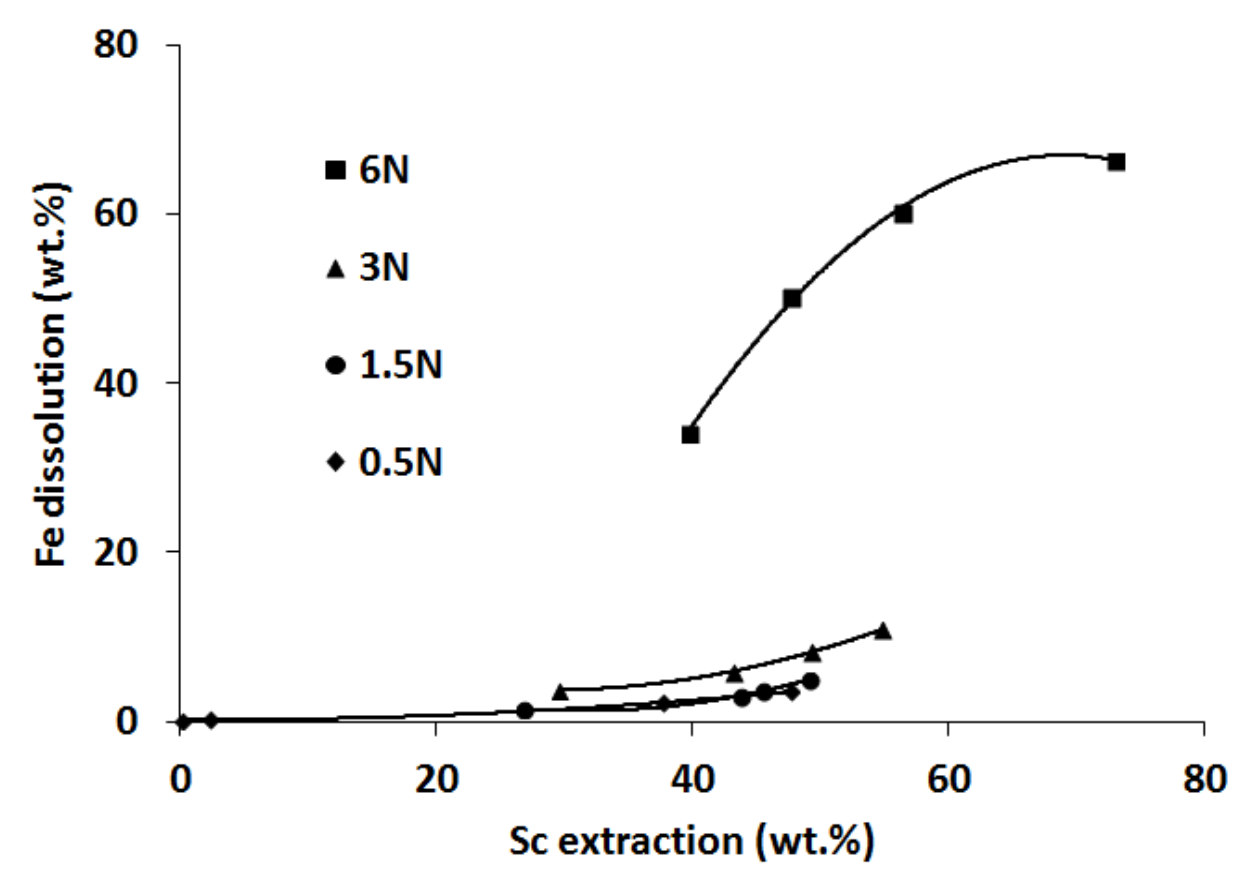

Figure 12. Dissolution behavior of iron and scandium in $\mathrm{HCl}$ with different acid concentrations (T: $25{ }^{\circ} \mathrm{C}, \mathrm{t}: 24 \mathrm{~h}$ ). Each acid concentration curve consists of data points with changing L/S ratio (low Sc extraction is associated with low L/S, high extraction with high L/S).

\subsection{Effect of leaching time and temperature}

Leaching experiments were carried out at different time intervals (between 5 min and 24 h) to study the effect of time on the extraction of different elements (Figure 13). The acid concentration was varied from $0.5 \mathrm{~N}$ to $3 \mathrm{~N}$. The $\mathrm{L} / \mathrm{S}$ ratio was kept constant in these experiments, i.e. $\mathrm{L} / \mathrm{S}=50: 1$. It can be observed that the extraction of REEs in the solution is increasing with time and the effect is more pronounced at the start of the leaching experiments with low acid concentration. The effect is more prominent for $\mathrm{Ce}, \mathrm{La}$ and $\mathrm{Fe}$ at $3 \mathrm{~N}$ acid concentration and their dissolutions are improving slightly up to $24 \mathrm{~h}$. 
Postprint of C.R. Borra, Y. Pontikes, K. Binnemans, T. Van Gerven (2015). Leaching of rare earths from bauxite residue (red mud). Accepted for publication in Minerals Engineering.
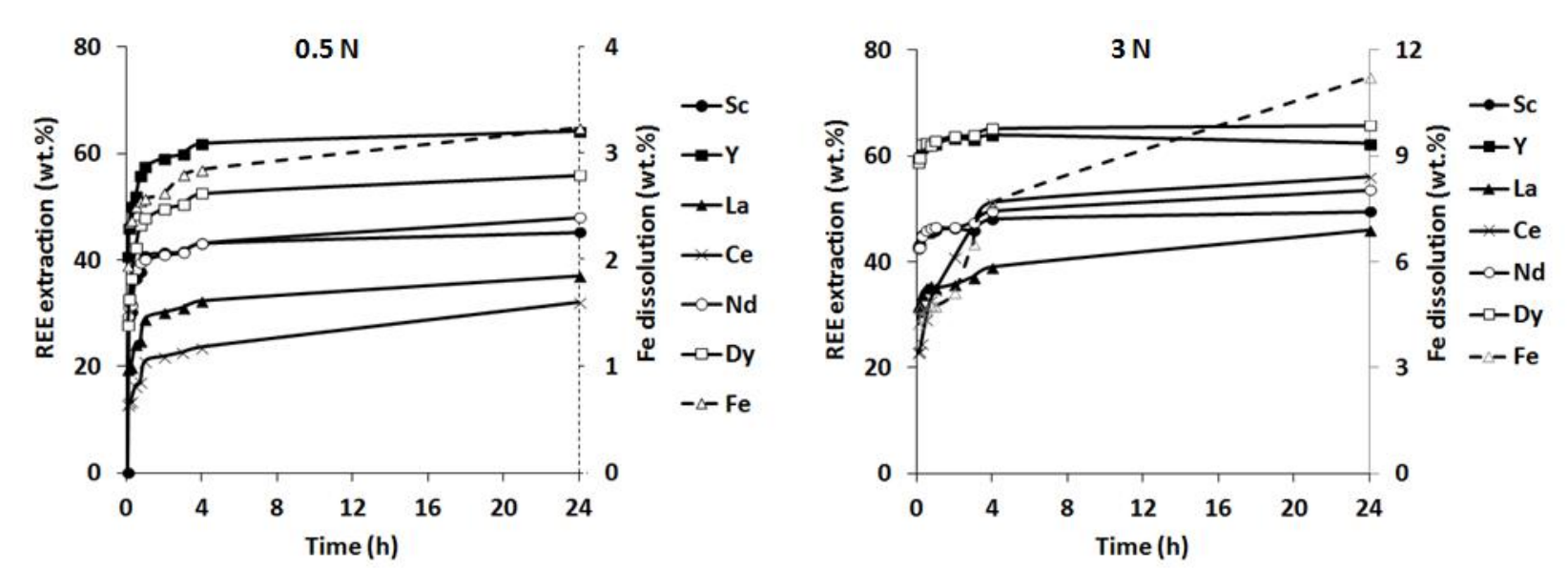

Figure 13. Effect of leaching time on extraction of REEs and iron in bauxite residue at two different acid concentrations ( $\left.\mathrm{HCl}, \mathrm{T}: 25^{\circ} \mathrm{C}, \mathrm{L} / \mathrm{S}: 50\right)$.

The effect of leaching temperature was studied at $0.5 \mathrm{~N}$ acid concentration and an L/S ratio of 50:1 with $\mathrm{HCl}, \mathrm{H}_{2} \mathrm{SO}_{4}, \mathrm{HNO}_{3}$ and citric acid for the duration of $1 \mathrm{~h}$. There is no significant improvement in leaching for the mineral acids by increasing the temperature. For citric acid it was observed that an increase in temperature does increase the extraction of REEs substantially. Figure 14 shows the effect of citric acid on leaching of Sc, Y, Ce and Fe at different temperatures. Extraction of REEs from bauxite residue with citric acid at temperatures above 90 ${ }^{\circ} \mathrm{C}$ is comparable with that of mineral acids at room temperature. 


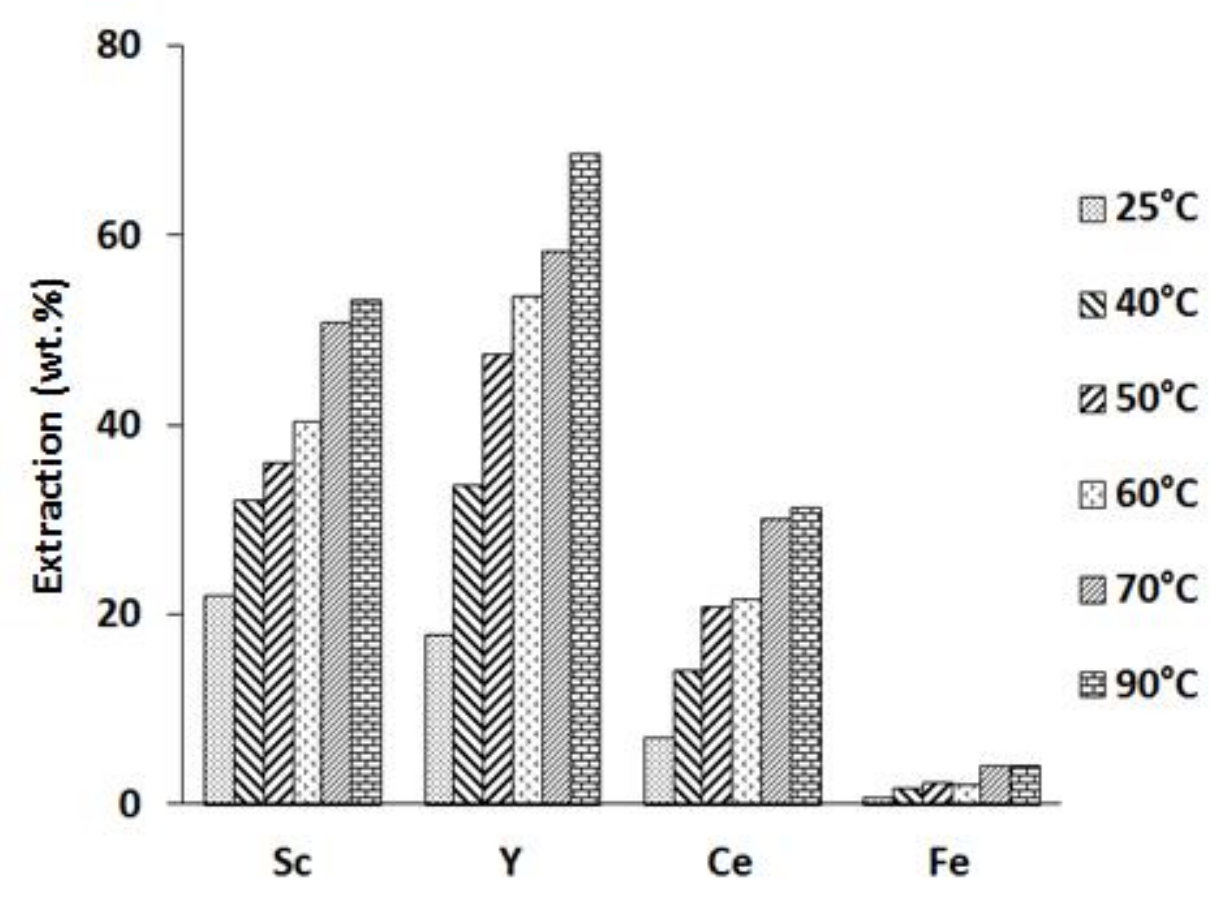

Figure 14. Effect of temperature on leaching with citric acid (0.5 N, L/S: 50, t: $1 \mathrm{~h})$.

\section{CONCLUSIONS}

The bauxite residue sample was a very fine material, with $90 \mathrm{wt} . \%$ of the material having a particle size of less than $10 \mu \mathrm{m}$. The main minerals observed in the bauxite residue were gibbsite, diaspore, hematite, calcite and cancrinite. The concentration of the rare-earth elements (REEs) in the studied bauxite residue was around $0.1 \mathrm{wt} . \%$. Water washing had a very low impact for decreasing the $\mathrm{pH}$ of the slurry and sodium content. REE recoveries were similar in all acids at low acid concentrations $(<1 \mathrm{~N})$, except for citric and acetic acid, which yielded lower recoveries. Initially, acid was consumed for the neutralization of the alkali and aluminosilicates. Extraction of REEs increased with acid concentration, time and L/S ratio. Extraction of the REEs was the highest for $\mathrm{HCl}$ leaching compared to other acids, but the iron leaching was also high ( $60 \%)$. Around $70-80 \%$ of the REEs could be recovered from the bauxite residue using $6 \mathrm{~N} \mathrm{HCl}$ leaching for $24 \mathrm{~h}$ duration at temperature of $25^{\circ} \mathrm{C}$. Most of the $\mathrm{Na}$ and $\mathrm{Ca}$ in the bauxite residue 
Postprint of C.R. Borra, Y. Pontikes, K. Binnemans, T. Van Gerven (2015). Leaching of rare earths from bauxite residue (red mud). Accepted for publication in Minerals Engineering.

dissolved into the solution during leaching. Extraction of Al, Si and Ti was around 30-50\%.

Increasing the leaching temperature did not improve recoveries for mineral acids at $0.5 \mathrm{~N}$, but it helped in the case of citric acid leaching: the REE leaching results for citric acid above $90{ }^{\circ} \mathrm{C}$ were comparable those for mineral acids at $25^{\circ} \mathrm{C}$. The leaching data show that scandium in bauxite residue is very closely associated with iron.

\section{ACKNOWLEDGEMENTS}

This research was funded by DBOF grant from KU Leuven to CRB and supported by the Research Platform for the Advanced Recycling and Reuse of Rare Earths (IOF-KP RARE ${ }^{3}$ ). The KU Leuven Department of Earth and Environmental Sciences is acknowledged for the use of TGA and XRD equipment. YP is thankful to the Research Foundation Flanders (FWO) for the post-doctoral fellowship. The authors thank Aluminum of Greece for providing the bauxite residue sample.

\section{REFERENCES}

Agatzini-Leonardou, S., Oustadakis, P., Tsakiridis, P. E., Markopoulos, C., Titanium leaching from red mud by diluted sulfuric acid at atmospheric pressure. Journal of Hazardous Materials, 2008, 157(2), 579-586.

Bárdossy, G., Karst Bauxites. 1982, Elsevier, Amsterdam.

Brookins, D. G., Scandium. In Eh-pH Diagrams for Geochemistry. Springer Berlin, Heidelberg, 1988, pp. 120-121. 
Postprint of C.R. Borra, Y. Pontikes, K. Binnemans, T. Van Gerven (2015). Leaching of rare earths from bauxite residue (red mud). Accepted for publication in Minerals Engineering.

Binnemans, K., Pontikes, Y., Jones, P.T., Van Gerven, T., Blanpain, B., Recovery of rare earths from industrial waste residues: a concise review, In Proceedings of the 3rd International Slag Valorisation Symposium: the Transition to Sustainable Materials Management, Leuven (Belgium), 2013, pp. 191-205.

Fulford, G.D., Lever, G., Sato, T., 1991. Recovery of rare earth elements from Bayer process red mud. US Patent 5,030,424.

Klauber, C., Gräfe, M., Power, G., Bauxite residue issues: II. options for residue utilization. Hydrometallurgy, 2011, 108(1), 11-32.

Kumar, S., Kumar, R., Bandopadhyay, A., Innovative methodologies for the utilisation of wastes from metallurgical and allied industries. Resources, Conservation and Recycling, 2006, 48(4), 301-314.

Li, Z., Din, J., Xu, J., Liao, C., Yin, F., Lü, T., Cheng, L., Li, J., Discovery of the REE minerals in the Wulong-Nanchuan bauxite deposits, Chongqing, China: Insights on conditions of formation and processes. Journal of Geochemical Exploration, 2013, 133, 88-102.

Mordberg, L., Patterns of distribution and behavior of trace elements in bauxites. Chemical Geology, 1993, 107(3), 241-244.

Ochsenkühn-Petropulu, M., Lyberopulu, T., Parissakis, G., Direct determination of landthanides, yttrium and scandium in bauxites and red mud from alumina production. Analytica Chimica Acta, 1994, 296(3), 305-313.

Ochsenkühn-Petropulu, M., Lyberopulu, T., Ochsenkühn, K., Parissakis, G., Recovery of lanthanides and yttrium from red mud by selective leaching. Analytica Chimica Acta, 1996, 
Postprint of C.R. Borra, Y. Pontikes, K. Binnemans, T. Van Gerven (2015). Leaching of rare earths from bauxite residue (red mud). Accepted for publication in Minerals Engineering.

319(1), 249-254.

Ochsenkühn-Petropoulou, M., Hatzilyberis, K., Mendrinos, L., Salmas, C., Pilot-plant investigation of the leaching process for the recovery of scandium from red mud. Industrial \& Engineering Chemistry Research, 2002, 41(23), 5794-5801.

Pontikes, Y., Angelopoulos, G., Bauxite residue in cement and cementitious applications: Current status and a possible way forward. Resources, Conservation and Recycling, 2013, 73, 53-63.

Power, G., Gräfe, M., Klauber, C., Bauxite residue issues: I. Current management, disposal and storage practices. Hydrometallurgy, 2011, 108(1), 33-45.

Qu, Y., Lian, B., Bioleaching of rare earth and radioactive elements from red mud using Penicillium tricolor RM-10. Bioresource Technology, 2013, 136, 16-23.

Roach, G. I. D., A study of the leaching of goethite and hematite, Doctoral dissertation, University of British Columbia, Canada, 1970.

Smirnov, D., Molchanova, T., The investigation of sulphuric acid sorption recovery of scandium and uranium from the red mud of alumina production. Hydrometallurgy, 1997, 45(3), 249-259.

Thornber, M., Binet, D., Caustic soda adsorption on Bayer residues, In 5th International Alumina Quality Workshop, Banbury (Australia), 1999, pp. 498-507.

Urbain, G., Sarkar, P. B., Sur les analogies du scandium avec les éléments des terres rares et avec les éléments trivalents de la famille du fer. Comptes Rendus, 1927, 185, 593-596.

Valeton, I., Bauxites. 1972, Elsevier, Amsterdam.

Wang, K.Q., Yu, Y.B., Wang, H., Chen, J., Experimental investigation on leaching scandium 
Postprint of C.R. Borra, Y. Pontikes, K. Binnemans, T. Van Gerven (2015). Leaching of rare earths from bauxite residue (red mud). Accepted for publication in Minerals Engineering.

from red mud by hydrochloric acid. Chinese Rare Earths, 2010, 1, 95-98.

Wang, W., Pranolo, Y., Cheng, C.Y., Metallurgical processes for scandium recovery from various resources: A review. Hydrometallurgy, 2011, 108, 100-108.

Wang, W., Pranolo, Y., Cheng, C.Y., Recovery of scandium from synthetic red mud leach solutions by solvent extraction with D2EHPA. Separation and Purification Technology, 2013, 108, 96-102.

Xue, A., Chen, X., Tang, X., The technological study and leaching kinetics of scandium from red mud. Nonferrous Metals Extractive Metallurgy, 2010, 2, 51-53.

Yatsenko, S., Pyagai, I., Red mud pulp carbonization with scandium extraction during alumina production. Theoretical Foundations of Chemical Engineering, 2010, 44(4), 563-568.

Zhang, J., Deng, Z., Xu, T., Experimental investigation on leaching metals from red mud. Light Metals, 2005, 2, 13-15. 